\title{
KRONIKA
}

DARIUSZ STĘPKOWSKI*

Warszawa, Polska

ORCID ID: https://www.orcid.org/oooo-0oo2-6855-1517
Forum Pedagogiczne

$10(2020) 1$

Wpłynęło: 16.11.2019

Zatwierdzono do druku: 18.03 .2020

DOI: $10.21697 /$ fp.2020.1.24

\section{Sprawozdanie z europejskiego sympozjum naukowego pt. „Der Fall des Eisernen Vorhangs und die Folgen - Europäisch Pädagogische Perspektiven”, Wiedeń (Austria), 2-3 listopada 2019 roku}

Sympozjum odbyło się w Instytucie Nauk o Kształceniu (Institut für Bildungswissenchaften) Uniwersytetu Wiedeńskiego z okazji 3o. rocznicy zerwania żelaznej kurtyny w Europie Wschodniej i Środkowej. Pomysłodawcą i głównym organizatorem spotkania naukowego był Henning Schluss, kierownik Katedry Pedagogiki Ogólnej na wspomnianym uniwersytecie. W dwudniowych obradach wystąpiło 10. prelegentów z siedmiu krajów, z tego czterech z Austrii, dwóch z Czech i po jednym z Niemiec, Polski, Rumunii, Węgier i Kazachstanu. Obrady podzielono na sesję inauguracyjną i pięć sesji tematycznych, z których trzy odbyły się pierwszego dnia, a dwie drugiego.

Na początku zgromadzonych powitał główny organizator - H. Schluss. Zwrócił on uwagę, że w tytule sympozjum celowo użyto zwrotu „żelazna kurtyna”, a nie „Mur Berliński”, żeby podkreślić europejską, a nie niemiecką perspektywę patrzenia na wydarzenia sprzed trzech dziesięcioleci. Po nim głos zabrał dziekan Wydziału Filozoficznego i Nauk o Kształceniu Wilfried Datler, który oprócz kurtuazyjnego powitania uczestników sympozjum, podzielił się osobistymi doświadczeniami związanymi z podziałem Europy na dwie części - socjalistyczną i kapitalistyczną, i upadkiem hegemonii Rosji sowieckiej w Europie Wschodniej i Środkowej. Następnie poproszono o zabranie głosu pochodzącą z Rumunii Gudrun Gutt, jako tzw. keynote speaker, czyli główną prelegentkę. Mimo że nie jest ona naukowcem, organizatorzy powierzyli jej zadanie wprowadzenia w tematykę sympozjum. Wynikało to stąd, że G. Gutt jako pracownik Radia Austriackiego (Österreichische Rundfunk) uczestniczyła bezpośrednio w wydarzeniach z końca 1989 roku w Rumunii. Będąc odpowiedzialną za informacje z Europy Wschodniej, ze szczególną uwagą śledziła skąpe wieści dochodzące ze swojego ojczystego kraju, rządzonego wówczas przez Nicolae Ceaușescu i jego rodzinę. Prelegentka

* Dr hab. Dariusz Stępkowski, profesor UKSW, Uniwersytet Kardynała Stefana Wyszyńskiego w Warszawie, Wydział Nauk Pedagogicznych; e-mail: d.stepkowski@uksw.edu.pl. 
zatytułowała swój referat War es eine oder war es keine Revolution?. Prześledziła w nim wydarzenia z przełomowego dla Rumunii roku 1989, w którym upadła dyktatura Ceaușescu. Oprócz osobistych doświadczeń wykorzystała materiały telewizyjne i radiowe, które wówczas emitowano w mediach rumuńskich i zagranicznych. Odpowiadając na pytanie zawarte w tytule referatu - „Była to rewolucja czy nie?”, Gutt stwierdziła, że jej zdaniem do dziś kwestia ta pozostaje nierozstrzygnięta, co więcej, staje się problemem, na który być może dopiero teraz, tzn. po latach, będzie można odpowiedzieć.

Po przerwie na kawę rozpoczęto pierwszą sesję tematyczną, w której zaprezentowano dwa referaty. Obaj prelegenci pochodzili z Czech. Jako pierwszy głos zabrał Tomáš Kasper z Instytutu Pedagogiki Wydziału Nauk Humanistycznych Uniwersytetu Technicznego w Libercu. Tytuł jego referatu brzmiał: Die ganze Bildungsgeschichte umschreiben, alles umschreiben - zur Umschreibungskultur und ihrer Folgen in der marxistischen pädagogischen Diskussion in der Tschechoslowakei. Wychodząc od potrzeby napisania od nowa historii edukacji czechosłowackiej, T. Kasper przedstawił proces sowietyzacji pedagogiki czechosłowackiej po drugiej wojnie światowej. Jego zdaniem mocodawcom socjalistycznej praktyki edukacyjnej chodziło o stworzenia warunków do implementacji idei nowego, socjalistycznego człowieka. W tym kontekście mówca prześledził powojenny dyskurs pedagogiczny odnośnie tzw. szkoły jednolitej. Model ten przedstawiano wówczas jako oryginalny pomysł sowiecki, pomijając całkowitym milczeniem dyskusję, która odbyła się na ten temat w Czechosłowacji w latach 1929-1939. Zdaniem T. Kaspera, idea oświaty jednolitej została nie tylko nadużyta przez socjalistyczną propagandę i wiernopoddańczych rodzimych pedagogów do sowietyzacji ówczesnego społeczeństwa czechosłowackiego, lecz również ideologicznie wypaczona.

Drugim prelegentem z Czech był Tomáš Janík z Uniwersytetu Masaryka w Brnie, który przedstawił referat pt. Aktuelle Entwicklungen im Bildungsbereich in der Tschechischen Republik: 30 Jahre nach dem Fall des Eisernen Vorhangs. W składającym się z czterech punktów wystąpieniu naszkicował najpierw liczącą 100 lat historię budowania systemu oświatowego w Czechosłowacji i Czechach. Okres ten podzielił na trzy etapy: międzywojenny, socjalistyczny i współczesny, tzn. po przełomie politycznym w 1989 roku. W drugim punkcie prelegent skupił się na dziejach systemu oświatowego w ostatnim trzydziestoleciu. Okres ten podzielił na trzy fazy: (1) powrót do tego, co było przed wojną (1989-2001); (2) poszukiwanie nowego modelu kształcenia (2001-2013) i (3) zastanawianie się nad przyszłością (2013-2020). Do prześledzenia zmian zachodzących w tych trzech fazach najnowszej historii czeskiego systemu oświatowego T. Janík posłużył interesującym narzędziem - governance analysis. Do tej analizy przyjął i porównał ze sobą cztery zakresy: (1) ukierunkowanie na efekty ustalone przez instytucje państwowe; (2) procesy kierowane przez nauczycieli; (3) ukierunkowanie na zdawalność testów zewnętrznych i (4) orientacja na potrzeby runku pracy. W trzecim punkcie T. Janík scharakteryzował z pomocą governance analysis aktualny okres rozwoju systemu 
oświatowego w Czechach - zastanawianie się nad przyszłością. Na zakończenie, w czwartym punkcie, przedstawił kilka wskazań wynikających z jego analiz odnośnie pytania o przyszłość.

Po wystąpieniach odbyła się dyskusja, a po niej przerwa na kawę. Potem wznowiono obrady. W drugiej sesji tematycznej zgromadzeni połączyli się za pomocą Skype'a z Zhanną Sagyndykovą z Kazachstanu i wysłuchali jej referatu pt. Voices to be heard: the role of teachers as major stakeholders education reforms in Kazakhstan. Z. Sagyndykova jest zatrudniona na University of Plymouth i pełni funkcję koordynatora projektu zleconego przez Ministerstwo Edukacji Kazachstanu grupie naukowców z Uniwersytetu Harvarda w Stanach Zjednoczonych Ameryki. Badaczom powierzono zadanie przeprowadzenia ewaluacji kazachskiego systemu edukacyjnego, jego potrzeb i możliwości. Projekt rozpoczął się w 2014 roku i dobiegł końca w roku 2019. Z. Sagyndykova zwróciła uwagę na wielorakie trudności, na które natrafiono podczas jego realizacji, w tym brak dostępu do koniecznych danych i niezrozumienie ze strony władz oświatowych odnośnie celu badania. Nawiązując do tytułu swojego wystąpienia, prelegentka podkreśliła, że najważniejszym zadaniem w reformowaniu oświaty kazachskiej jest udzielenie głosu nauczycielom. W związku z tym wypracowany program poprawy jakości kształcenia skierowany jest w pierwszym rzędzie do nauczycieli i obejmuje m.in. następujące działania: (1) szkolenia w zakresie uczenia się z własnych doświadczeń; (2) wzmacnianie lokalnego potencjału szkół i (3) prowadzenie niezależnej ewaluacji jakości kształcenia przez poszczególne placówki oświatowe. Tak jak poprzednio odbyła się dyskusja, podczas której pytano prelegentkę m.in. o postsowieckie dziedzictwo w Kazachstanie.

Jak drugi w tej sesji tematycznej wystąpił Alan Ross z miejscowego Instytutu Nauk o Kształceniu. Przedstawił on referat zatytułowany: Comenius and the national question before and after 1989. Pochodzący z Polski młody historyk wychowania nakreślił sylwetkę Jana Amosa Komeńskiego i jego znaczenie w kształtowaniu się myślenia pedagogicznego w Europie. Po tym referacie gospodarze zaprosili uczestników na kolację, a po niej odbyła się jeszcze jedna sesja tematyczna.

Trzecią sesję rozpoczął niżej podpisany. Tytuł jego referatu brzmiał: Von der (sozialistischen) Erziehungstheorie zur Meta-Pädagogik. Frage nach der Notwendigkeit Allgemeiner Pädagogik in Polen nach dem Fall des Eisernen Vorhangs. Przesłanką do refleksji nad pytaniem o potrzebę pedagogiki ogólnej w Polsce stanowił dla prelegenta $\mathrm{z}$ jednej strony proces rewitalizacji myślenia ogólnopedagogicznego, z drugiej zaś nieobecność pedagogiki ogólnej jako odrębnej subdyscypliny nauk(i) o wychowaniu w wydanym w 2019 roku kompendium wiedzy pedagogicznej pt. Pedagogika, pod redakcją naukową Zbigniewa Kwiecińskiego i Bogusława Śliwerskiego. W referacie została rozważona koncepcja pedagogiki ogólnej jako metapedagogiki, którą zgłosił w tymże kompendium drugi z wymienionych autorów w ramach opracowania naukowych podstaw pedagogiki. 
Drugi referat w tej sesji wygłosiła Christine Salmen z wiedeńskiego Instytutu Nauk o Kształceniu. Tytuł jej wystąpienia brzmiał: Tot inainte, mandru pionier! Der Umbruch in Rumänien. W pewnym sensie była to kontynuacja referatu wprowadzającego G. Gutt. Prelegentka przedmiotem swojego badania uczyniła różnorodność interpretacji i oceny faktów historycznych. C. Salmen przeprowadziła wywiady z naocznymi świadkami rewolucyjnych przemian w Rumunii w 1989 roku, a następnie, posługując się metodą fenomenograficzną, przeanalizowała podobieństwa i różnice ujawniające się nie tylko w sposobie odczytywania sensu tamtych wydarzeń, lecz także ich historycznych komponentów. Ostatnim akordem tego wystąpienia było zaproszenie do wspólnego obejrzenia filmu dokumentalnego pt. Chuck Norris vs Comunism (2015), którego realizatorzy na taśmie filmowej uwiecznili podobne wywiady do tych, jakie przeprowadziła C. Salmen.

Obrady wznowiono następnego dnia o godz. 9.30. Jako pierwszy w czwartej sesji głos zabrał Ulrich Wiegmann, emerytowany profesor Uniwersytetu Humboldtów i wieloletni współpracownik w Leibniz-Institut für Bildungsforschung und Bildungsinformation (DIPF) w Berlinie. Przedstawił referat zatytułowany Perspektivenwechsel - Der Mauerfall als herausforderndes Verhängnis. Na uwage zasługuje fakt, że w samym tytule prelegent przyjął perspektywę wewnątrzniemiecką. Przedmiotem jego referatu były losy prominentnych pedagogów Niemieckiej Republiki Demokratycznej (NRD) po 1989 roku. U. Wiegmann prześledził biografie Karla-Heinza Guenthera (1926-2010) - wieloletniego przewodniczącego Akademii Nauk NRD, Artura Meiera (1932-) - socjologa edukacji z Uniwersytetu Humboldtów i Gerharta Neunera (1929-2008) - ostatniego dyrektora Akademii Nauk Pedagogicznych NRD (Akademie der Pädagogischen Wissenschaften). Każdy $\mathrm{z}$ wymienionych prominentów napisał pod koniec swojego życia autobiografię, w której zawarł swoje wspomnienia z okresu NRD oraz przemyślenia i doświadczenia po zburzeniu Muru Berlińskiego. Na tej podstawie prelegent przyporządkował pierwszego z wymienionych do modelu pesymisty, który swoje życie i dokonania uznał za bezwartościowe. Drugi prominent reprezentuje, zdaniem U. Wiegmann, model pragmatyka, który postanowił odnaleźć swoje miejsce w zmienionej rzeczywistości. W przypadku A. Meiera oznaczało to wycofanie się z życia publicznego i poświęcenie się całkowicie rodzinie. G. Neuner był według prelegenta uosobieniem modelu kontestatora, który nigdy nie pogodził się ze zmianą historyczną. Co więcej, nie przyjął jej w ogóle do wiadomości. Dla G. Neunera w 1989 roku czas jakby się zatrzymał.

W dyskusji zwrócono uwagę na trudną sytuację, w jakiej znaleźli się enerdowscy naukowcy po zburzeniu Muru Berlińskiego. Z jednej strony zostali z dnia na dzień pozbawieni miejsc pracy i możliwości prowadzenia działalności naukowej, z drugiej zaś ciążyło na nich piętno reprezentantów dawnego systemu.

Jako druga w tej sesji głos zabrała Sabine Krause z Uniwersytetu w Insbrucku (Austria). Przedstawiła referat pt. Staaken feiert Wiedervereiningung (Spandauer Volksblatt). (Auto)Biographische und fotografische Reminiszenzen. Jej projekt 
badawczy polegał na zgromadzeniu materiału fotograficznego dotyczącego podberlińskiej miejscowości o nazwie Staaken, która po wojnie została podzielona na dwie części - wschodnią i zachodnią. Pierwsza z nich należała do socjalistycznego Berlina Wschodniego, a druga do kapitalistycznego Berlina Zachodniego. Losy mieszkańców obrazują, zdaniem S. Krause, w miniaturze powojenne losy Niemiec. Zgromadzenie materiału fotograficznego nie było wcale łatwym przedsięwzięciem, gdyż w NRD obowiązywał zakaz fotografowania, w szczególności strefy nadgranicznej. Pozyskane i niejednokrotnie cudem zachowane zdjęcia badaczka wzbogaciła wywiadami z rodowitymi mieszkańcami Staaken, skąd notabene sama pochodzi. Na tej podstawie przygotowała opracowanie o charakterze badania jakościowego. W referacie podzieliła się ze zgromadzonymi swoimi doświadczeniami badawczymi.

Po przerwie na kawę przystąpiono do piątej i ostatniej sesji. Złożyły się na nią dwa referaty. Pierwszy wygłosili Henning Schluß i Hanna Holzapfel z miejscowego Instytutu Nauk o Kształceniu, którzy przedstawili temat: Auch eine Dialektik der Aufklärung - Die Öffnung der Archive und die folgenden Enttäuschungen - Der Fall Lutz Bertram. Poddali oni analizie postać Lutza Bertrama, wieloletniego redaktora radiowego rozgłośni Wschodnioniemieckie Radio Brandenburgia (Ostdeutsche Rundfunk Brandenburg), który w latach 1991-1995 cieszył się ogromną popularnością dzięki prowadzeniu porannego program „Auftakt”. Poszukując przyczyn jego popularności, prelegenci zwrócili uwagę na trzy elementy w biografii L. Bertrama: (1) był on osobą ociemniałą, a w ostatnim okresie zupełnie niewidomą; (2) mówił dialektem wschodnioniemieckim i (3) w latach 1980-1989 współpracował ze STASI, wschodnioniemiecką służbą bezpieczeństwa. Ten fakt został ujawniony w roku 1995 i spowodował usunięcie go z pracy. Niemniej jednak, zdaniem H. Schlussa i H. Holzapfel, właśnie ta skrywana przeszłość paradoksalnie powodowała, że L. Bertram na falach eteru często podejmował kwestie dotyczące socjalistycznej przeszłości i współpracy ze STASI. Jedną z jego interlokutorek była słynna pisarka Christa Wolf. Wiedeńscy badacze zwrócili uwagę, że nie chodzi im o moralną ocenę człowieka, lecz o pytanie, jaki wpływ wywarła jego przeszłość na rolę „luminarza”, którą otwarcie przypisywał sobie L. Bertram do chwili, gdy nie wyszła na jaw jego własna przeszłość.

Jako ostatniego zgromadzeni wysłuchali Zoltana Miklosi'a z Central-European University w Budapeszcie (Węgry), który przedstawił referat zatytułowany: Constitutional hardball and democratic back-sliding: lessons from Hungary. Wychodząc od diagnozy aktualnej sytuacji politycznej na Węgrzech - upadku demokracji, Z. Miklosi poszukiwał w przeszłości węgierskiej czynników, które powodują, jego zdaniem, obecnie apatię narodu i hegemonię jednej opcji politycznej.

$\mathrm{Na}$ zakończenie głos zabrał Henning Schluss, który podziękował gościom za przybycie do Wiednia i owocne obrady. 